\title{
The Impact of Managerial Ownership on the Cash Holdings in the Cement Sector of Pakistan
}

\author{
MUHAMMAD SOHAIL KHALIL \\ Assistant Professor, City University of Science an I.T, Peshawar \\ khalilims@gmail.com \\ MUHAMMAD AAMIR NADEEM \\ Assistant Professor, City University of Science an I.T, Peshawar \\ MUHAMMAD TAHIR KHAN \\ Lecturer, Abdul Wali Khan University, Mardan \\ SAQIB SHAHZAD \\ Demonstrator, Abdul Wali Khan University, Mardan \\ PhD-Scholar. Institute of Management Sciences, Peshawar \\ Saqibshahzad26@gmail.com
}

\begin{abstract}
The study aims to investigate the impact of managerial ownership on the cash holdings in cement sector of Pakistan. For the purpose 15 Companies were selected from the sector as the rest were delisted from Pakistan stock exchange. The independent variables such as managerial ownership, institutional ownership and annual profit and leverage ratios were tested against the dependent variable cash holdings for the period of 09 years. Panel data was taken i.e. from 2007 to 2015 from business recorder and respective websites of the companies. Multiple regression model was used to determine the relationship between the variables further ANOVA test was also used to check overall association of independent variables on cash holding yielding positive and significant results.
\end{abstract}

Key words: Managerial ownership, Leverage, Cash holdings and Institutional ownership

\section{Introduction}

In recent years various attempts have been made to discuss the issue of cash holding in Pakistan. Different factors like market to book ration, leverage, cash volatility, and cash conversation cycles have been tested by various authors. It was found that firms with higher cash flow tend to maintain higher cash balance too. The very idea of cash holding has been studied in a light of theories like trade off theory, free cash flow theory and Pecking Order Theory (Keynes 1936). According to trade off theory, firms compare the additional costs and additional benefits by holding excess cash. Free cash flow theory says that managers and to hold excess cash so that to increase their discretionary power regarding investment decisions. Similarly the Pecking order theory suggests that firm 
primarily finance the investment with the retained earnings then safe debt and then lastly with risky debt. In Pakistan firms hold $13.1 \%$ cash for investment and financing purpose. Two of such cases were the Oil and Gas Development Company (OGDC) and Fauji Company (FFC). The cash balance difference of OGDC during the year 2003 was recorded to be Rs. 6 Billion. A good number of researches across the globe also showed a significant relationship between managerial ownership and corporate cash holdings. Similarly we have also a great amount of efforts shown about the cash holdings in Pakistan context; however no one has emphasized on the managerial ownership, institutional ownership and other agency related issues in Pakistani firms. This paper will specifically study the impacts of managerial ownership and other agency problems in Companies listed in Karachi Stock Exchange. Further will explore the agency problems which exist in the sample.

\subsection{Problem Statement}

Analyzing the impact of managerial ownership on the cash holdings decisions of cement sector of Pakistan from 2007-2015.

\section{2 Objectives of the Study}

To investigate

- The effects of managerial ownership on the cash holdings in the cement sector of Pakistan.

- The relationship of managerial ownership to that of the company's cash holdings decisions.

\subsection{Purpose of the Study}

Seeking comprehensive knowledge of the relationship of managerial ownership of the companies listed in the Pakistan stock exchange to the company's cash holdings decisions. An effort will also put to dig into agency problems in the given population.

\subsection{Scope of the study}

The study is only applicable to the cement companies that are listed in Karachi stock exchange. However, its results may be generalized to other sectors under similar conditions.

\section{Literature Review}

Niskanen and Steijvers (2010) studied around 600 Finnish SMEs to figure out the effects of Managerial Ownership on the cash holdings of these firms. For this purpose they employed a panel data with observations ranging from 2000-2005. They applied appropriate regression model to conclude that cash holdings were the most in the companies with no managerial ownership and the lowest in the firms with a certain level of Managerial Ownership. Anderson \& Reed (2003) used Standard \& Poor 500 firms from 1993 to 1999 to check the effects of family ownership on the firm's performance. The data was taken from the COMPUSTAT files with 2713 yearly observations. The results revealed the substantial existence of family ownership in standards and poor 500 firms. The results also showed that family owned business performed better than nonfamily firms, it was further observed that the relationship between family ownership and firm's performance was nonlinear and that in the firms where the CEO was a family member, performed better than the firm with outsider CEOs. Lozano (2011) tested the 
effect of cash holdings on firm's value by selecting 119 Spanish non-financial firms. Taking an unbalanced panel comprising 830 observations from the public database, he concluded that Investments undertaken by Low Investment Opportunities (LIO) firms positively affects the firm's valve. Results also showed a positive relationship between dividend policy and cash holdings with those firms which lave lower investment opportunities. Pinkowitz and Williamson (2001) used PACAP files of Japanese firms from 1974-1995 to found out the effect of bank power on a firms cash holdings. They also did a cross country analysis to come up which country's firms hold more cash balances between Japan, Germany and USA. The results approved higher cash balance in Japanese's firms. Furthermore, the results also showed a highly positive relationship between bank power and cash holdings. Azmat (2011) cash holdings have a positive relationship with cash flows but negative relationship with leaverage. Cash holdings of mature firms are higher than growth firms. She used the data of 261 Karachi Stock Exchange listed firms, a total of 1566 observations from 2003-2008. According to the results, the determinants of cash holdings were almost the same for mature and growth except: dividend payment having a negative relations with cash for growth firms and size having a negative relation with cash for mature firms.

Gill and Shah (2013) worked on a sample of 166 Canadian firms listed at Toronoto stock Exchange from 2008-2013 to find out that market to book ration, cash flows, net working capital leverage, firm size CEO Chairman Duality significantly affect the cash holdings Afza\&Adan (2007) firms on the average hold $13.1 \%$ cash for investment and financing purpose. The regression results showed significant effect of variables in the model, they used a sample of 205 Karachi stock Exchange listed firm for a period of 8 years (1998-2005). Shah .A (2010) used a sample of 280 firms have a period 1996-2008 to answer a question that firm is developing countries have larger debt, do they have larger Cashes balances too, the study employed both statistic and Dynamic data model. Static model showed that growing firms, large firms, dividng paying firms and firms with higher cash flows have more cash balances thus proving a positive relationship among them. Similarly firms with longer maturity of debt and firms with quick conversation cycle have less cash balances hence indicating a negative relationship. Okzan\&Okzan 92004) propose non-monotonic relationship between cash holding and managerial ownership. They found that a decrease in the cash occurred when the managerial ownership rose to $24 \%$, a rise in cash balances when this percentage of managerial ownership becomes 64\% which would further plummet at the higher level of ownership. For this purpose a sample of 1029 publicly traded UK firms from 1984-1999 and were cross section ally analyzed.

Anjum and Malik (2013) studied a sample of 395 Karachi Stock Exchange listed companies to check the effect of factors like size of the firm, leverage, Net Working Capital, cash conversion cycles and sales growth of the cash holdings of firm. They used different statistical tools like descriptive statistics, Pearson correlation, multiple regression and ANOVA. The only concluded to find significant relationship with all the variables under study except sales growth which is no impact on the on a firm's cash holding. Lawrenciaet. al(2013) worked on the relationship of cash holdings and a firm's 
Characteristics by taking a sample of 54 Nigerian firms listed at Nigerian Stock Exchange for a period of 15 years starting from 1995 to 2010. The research applied Correlational research designed on variables like a firm size, market to book ratio, investment opportunities, leverage, cash flow, ROI, INV and negative but significant relationship with NWC. Regression showed a significant positive relationship of leverage, ROI, INV and negative relationship of NWC except from MTV and size that have significant positive impact of cash holdings. Ferreire and Vilela (2004) the EMU countries had $15 \%$ of their total book value of assets and cash which amounted to be 303 billion to a firm average of 368 million. In this empirical study a sample of publically traded firms taken from EMU countries. A total of 6387 firm year observation were analyzed through regression. The results provided evidence for a significant negatively relationship between bank debt and cash holdings. Firms operating in countries which provide greater protection for investments tends to hold more cash. Campebel and Brandsel (1977) studied US firms during the period 1953-1963 to examine the effects of compensating balances requirements on the cash holdings. They have used the Millers and Orr's Ols regression of the target cash balances over the cash holdings of the firms to conclude that compensating cash balances are not binding. They have also verified their results using a technique called Cochren Orchut technique.

\subsection{Hypothesis Development}

\subsubsection{Managerial Ownership}

The literature suggest that in those companies where the executives and the CEOs hold more share or own more shares, those companies tend to reduce the annual cash holdings. They are more prone to distribute the retained earnings and dividends to the existing stock holders. Therefore, the first assumption of the research is; as the number of stock held by the executives and CEOs goes up in the cement companies of Pakistan, the amount of cash being held also keeps on decreasing.

$\boldsymbol{H}_{o}:$ Managerial ownership does not affect the company's holdings.

$\boldsymbol{H}_{1}$ : Managerial Ownership significantly affects the company's cash holdings.

\subsubsection{Institutional Ownership}

Prior studies suggest a relationship between the institutional investors and a firm's cash holdings. There, this study assumes that the institutional ownership is the cement sector of Pakistan significantly affects the company's cash holdings. So the hypothesis for this variable is as under.

$\boldsymbol{H}_{\boldsymbol{o}}$ : Institutional Ownership does not affect the company's cash holdings.

$\boldsymbol{H}_{1}$ : Institutional Ownership significantly affects the company's cash holdings.

\subsubsection{Annual Profits}

Depending upon the annual earnings of the company, the management plans for future investments, growth and research. So the second hypothesis of the research is the more the annual profits of the cement sector of Pakistan, the more is the amount of cash being retained for certain purpose. 
$\boldsymbol{H}_{\boldsymbol{O}}$ : There is no relationship between a firm's annual profits and the cash holdings.

$\boldsymbol{H}_{1}$ : There is a direct relationship between annual profits and cash holdings.

\subsubsection{Leverage}

It is the ration of firm total assets to a firm total debt. So if a firm relatively lesser debt in its capital structure, the leverage ratio would be greater and vice versa.But if a firm has larger proportion of debt, their firm will also have to bear its cost in the form of interest expense. So the third assumption of the research is; Leverage ratio lowers the cash holdings.

$\boldsymbol{H}_{\boldsymbol{o}}$ : There is no relationship between a firm's leverage ratio and its cash holdings.

$\boldsymbol{H}_{1}$ : There is a direct relationship between leverage ratio and cash holdings.

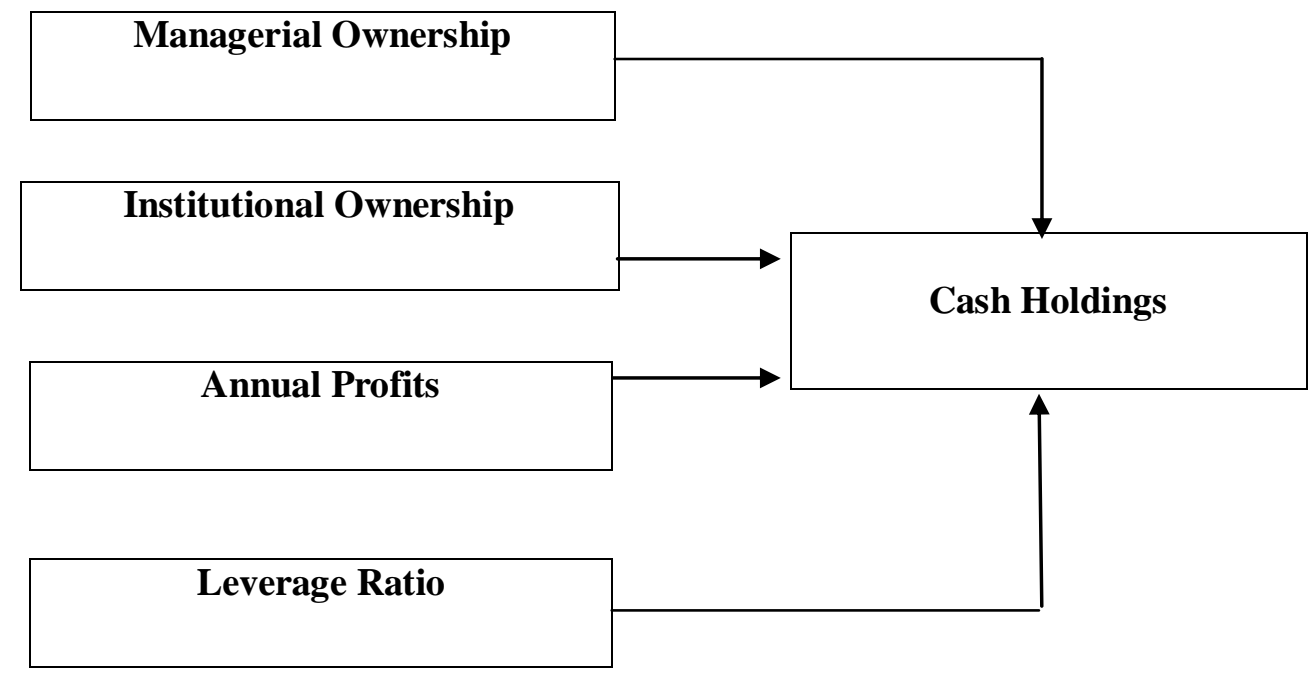

Figure 1: Theoretical Framework

The above diagram clearly hints towards the purpose and the need of the studies, as the researcher can see that the cash holdings of the cement companies in Pakistan can be affected by all the four listed variables namely, the managerial ownership, the institutional ownership, annual profits and lastly by the leverage ratio of the under study firm. However, the purpose of this study is to find out the ration by which firms cash holdings are affected by these variables.

\section{Methodology}

The current study is based on cement companies in Pakistan listed in Pakistan stock exchange from 2007-2015. A panel data of these will be extracted from balance sheet analysis of the specific firms, the selected company's annual reposts and from the websites of the firms and from www.psx.org.pk 


\subsection{Sample}

The study has used 15 listed cement companies of Pakistan. The study has almost covered all the Cement companies that are listed in Pakistan Stock Exchange. However, it has left aside the Defaulter companies as given there in the Pakistan Stock Exchange.

\subsection{Data Collection}

The study used a multiple regression model to interpret the panel data.

Cash holdings $=\alpha+\beta 1$ (Managerial Ownership) $+\beta 4$

(Institutional ownership) $+\beta 3$ (profits) $+\beta 4$ (leverage)

In the above equation, Cash holding is the Dependent Variable. So Cash refers to the annual cash and cash balances of the selected companies. The first independent variable in the equation is Managerial Ownership; it refers to the percentage of shares owned by the executives, their wives, kids and minors as given the annual reports of the selected companies owned by other institutions. The study has club up banks, insurance companies, modarabas and other companies together as one. The third independent variable is Annual Profits. The study has taken the annual net income after tax from the balance sheet of the sample. The last independent variable of the model is Leverage ratio. The study has considered the percentage of debt in the capital structure of the sample companies

\section{Results and Interpretation}

The study considered 15 listed cement companies of Pakistan from 2007 to 2015.For this purpose, panel data was executed annually from the annual reports of the companies selected. Data for the selected variables was taken in the following pattern:

\section{- Managerial Ownership}

The data for the above variable was taken in the percentage annually.

\section{- Institutional Ownership}

Data was extracted in percentage annually.

- Annual Profits

Annual profits were taken in Pakistani Rupee PKR

\section{- Leverage Ratio}

Data was taken in percentage annually.

\section{- Cash}

The data was taken in Pakistani Rupee PKR Annually.

The data was punched in a spread sheet in such a way that vertical columns contained the number of years in which data was taken along the horizontal axis, the selected variables were shown. The data was regressed in S.P.S.S and the results, therefore, obtained are as under. 
Table 4.1 Model Summary

\begin{tabular}{|lllll|}
\hline Model & $\mathrm{R}$ & $\mathrm{R}$ Square & Adjusted R Square & Std. Error of the Estimate \\
& & & & \\
\hline 1 & $.313 \alpha$ & .098 & .064 & $4.05202 \mathrm{E} 8$ \\
\hline
\end{tabular}

a. Predictors: (Constant), Leverage ratio, Institutional ownership, Annual profits, Managerial ownership.

The above table shows that adjusted R Square is 0.064 . It basically shows that the model used is less significant.

Table 4.2 ANOVA

\begin{tabular}{|c|c|c|c|c|c|}
\hline Model & $\begin{array}{l}\text { Sum } \\
\text { Squares }\end{array}$ & Df & $\begin{array}{l}\text { Mean } \\
\text { Square }\end{array}$ & $\mathbf{F}$ & Sig. \\
\hline Regression & $1.908 \mathrm{E} 18$ & 4 & $4.771 \mathrm{E} 17$ & 2.906 & .025 \\
\hline Residual & $1.757 \mathrm{E} 19$ & 107 & $1.642 \mathrm{E} 17$ & & \\
\hline Total & $1.948 \mathrm{E} 19$ & 111 & & & \\
\hline
\end{tabular}

a. Predictors: (Constant), Leverage, Profits, Managerial ownership

b. Dependent Variable: Cash \& Cash Equivalents.

The analysis of Variables table shows that significance is 0.025.It means that all the independent variables in the model have explained the dependent variable that is Cash holdings

Table 4.3 Coefficients

\begin{tabular}{|c|c|c|c|c|c|}
\hline Model & $\begin{array}{l}\text { Un-standar } \\
\text { Coefficients }\end{array}$ & dized & $\begin{array}{l}\text { Standardized } \\
\text { Coefficients }\end{array}$ & $\mathbf{t}$ & Sig. \\
\hline & B & Std. Error & Beta & & \\
\hline Constant & $4.732 \mathrm{E} 8$ & $1.087 \mathrm{E} 8$ & & 4.353 & .000 \\
\hline Managerial & $-4.987 \mathrm{E} 6$ & $1.898 \mathrm{E} 6$ & -.332 & -2.628 & .010 \\
\hline Institutional & $-4.065 \mathrm{E} 6$ & $1.713 \mathrm{E} 6$ & -.293 & -2.373 & .019 \\
\hline Profits & .048 & .033 & .134 & 1.435 & .154 \\
\hline Leverage & 315238.420 & 810554.671 & .037 & .389 & .689 \\
\hline
\end{tabular}

a. Dependent Variable: Cash 
The last table shows the significance of all the independent variables used in the model. The first variable is Managerial Ownership, with a significance of 0.01 , shows that there is a significant relationship between the Managerial Ownership and the Cash Holdings. The Beta for managerial ownership so obtained is -.332.The negative sign clearly indicates a negative relationship and .332 means, when the managerial ownership in the cement sector of Pakistan goes up by one unit, the cash holdings of the said companies reduce by .332 and if the managerial ownership goes down by one unit, subsequently the Cash holdings increase by 0.332 . The analysis gives a significance level of 0.019 for the second variable that is institutional ownership again suggesting a significant relationship between the institutional ownership and cash holdings. The Beta for this variable so obtained is -0.293.again the negative sign confirms a negative relationship between the Institutional ownership and the Firm's cash holdings. The Beta 0.293 means that if the Institutional ownership goes up by one unit in the selected firms, the cash would drop by 0.293, similarly if the institutional ownership goes down by one unit the cash would rise by 0.293 .For the third variable in the model, the annual profits, proved a significance of 0.15 which is greater than 0.05 so it is straight away accept Ho and hence concludes that there is no relationship between the annual profits and cash holdings of the Cement Sector of Pakistan .For the last variable of the model, the leverage ratio, showed a significance of 0.698.The study accept Ho that there is no relationship between the leverage and cash holdings.

\subsection{Conclusion}

The analysis shows that in Cement Sector of Pakistan, the Managerial Ownership significantly affect the company's annual cash holdings. Moreover, results also show a significantly negative relationship between the institutional owners and the cash holdings. On contrary, the results clarify that there is no relationship between the cement companies annual profits and leverage ratio to the company's annual cash holdings.

\subsection{Limitations}

The limitations for the study are listed as follows:

- The results will be limited to the firms listed in PSX.

- Data for managerial ownership is not clearly available

\subsection{Future Directions}

Similar researches can be carried out across other manufacturing sectors where heavy investments in fixed and current assets are a part of business routine

\section{References}

Afza, T., \& Adnan, S. M. (2007). Determinations of corporate cash holdings: Proceedings of Singapore Economic Review Conference (SERC), 164-165.

Anderson, R. C., \& Reeb, D. M. (2003). Founding of family ownership and firm performance: evidence from the S\&P 500. The journal of finance, 58(3), 13011328.

Anjum, S., \& Malik, Q. A. (2013). Determinants of corporate liquidity-An analysis of cash holdings. Journal of Business and Management, 7(2), 94-100.

Azmat, A. (2011). Corporate Cash Holdings: A Growth and Mature Firm Perspective in Pakistani Context. In 3rd International SAICON Conference.

Ferreira, M. A., \&Vilela, A. S. (2004). Why do firms hold cash? Evidence from EMU 
countries. European Financial Management, 10(2), 295-319.

Gill, A., \& Shah, C. (2012). Determinants of corporate cash holdings: Evidence from Canada. International Journal of Economics and Finance, 4(1), 70.

Keynes, J. M. (1936). The General Theory of Employment, Interest and Money, Harcout Brace and World. Inc, New York.

Lozano, M. B. (2012). Analyzing the effect of excess cash accumulation on financial decisions. Applied Economics, 44(21), 2687-2698.

Niskanen, M., \&Steijvers, T. (2010). Managerial ownership effects on cash holdings of private family firms.

Ogundipe, S. E., Salawu, R. O., \& Ogundipe, L. O. (2012). The determinants of corporate cash holdings in Nigeria: Evidence from general method of moments (GMM). World Academy of Science, Engineering and Technology,61, 978-984.

Ozkan, A., \& Ozkan, N. (2004). Corporate cash holdings: An empirical investigation of UK companies. Journal of Banking \& Finance, 28(9), 2103-2134.

Pinkowitz, L., \& Williamson, R. (2001). Bank power and cash holdings: Evidence from Japan. Review of financial studies, 14(4), 1059-1082.

Shah, A. (2011). The corporate cash holdings: Determinants and implications. 